\title{
ENTRE MILTON HATOUM E WERNER HERZOG
}

Dr. Daniel de Oliveira Gomes Professor adjunto do Departamento de Letras da Universidade Estadual do Centro-Oeste UNICENTRO. Guarapuava, Paraná.

\section{RESUMO}

Trata-se de uma resenha crítica do último romance de Milton Hatoum, "Órfãos do Eldorado", publicado pela editora Cia das Letras, em 2008. Nesta resenha, o relacionamos com o estilo expressionista do cineasta alemão Werner Herzog, que filmou o tema do "Eldorado", em algumas ocasiões, na selva amazônica.

PALAVRAS-CHAVE: Eldorado, Hatoum, Herzog

\section{ABSTRACT}

\section{About Milton Hatoum and Werner Herzog}

It's about a critical review about the last romance of Milton Hatoum, "Órfãos do Eldorado", published by Cia das Letras, in 2008. In this review, we relate it with the expressionist style of the German filmmaker Werner Herzog, who filmed the theme of "Eldorado", in some occasions, in the Amazon Rainforest.

KEY WORDS: Eldorado, Hatoum, Herzog

"Nós somos feitos do tecido que são feito os sonhos" (HERZOG, "Fitzcarraldo”, 1981).

"Órfãos do Eldorado", último romance do premiadíssimo manauense Milton Hatoum, publicado em 2008, lembra muito os filmes do famoso cineasta, do Novo Cinema Alemão, Werner Herzog. Hatoum tem toda "titulação", toda soberania, pra produzir um romance cujas imagens se apresentam nesse nível de nobreza expressionista, e, ao mesmo tempo, simplicidade. Pesa em seus ombros esta incumbência de ostentar um "eldorado" na literatura brasileira contemporânea, a cada livro que publica, podemos dizer como um monarca, ainda mais depois da consagração de três prêmios jabutis com seus primeiros romances. Ou seja, trata-se de um "duque" da literatura atual, quase um novo príncipe de quem todos esperamos a palavra, como não deixa de comprovar merecimento, uma vez mais, nesta sua bela história, publicada como romance pela Cia das Letras, mas que, de fato, é uma curta novela de 100 páginas encomendada por uma editora européia, da Escócia, para Série Mitos.

Porém, Hatoum, mesmo com todo regionalismo barroco de sua escritura, está órfão de uma pátria, de uma cidade, por mais que este livro seja justamente um ensaio de um tema tão tópico e histórico: o fim dos barões da borracha (que, diga-se de passagem, só acaba mesmo após a extrema exploração de látex comandada por Getúlio Vargas para financiar material bélico americano na Segunda Guerra). 
"então milhares de nordestinos foram trabalhar nos seringais. Soldados da borracha. Os cargueiros voltaram a navegar nos rios da Amazônia; transportavam borracha para Manaus e Belém, e depois os hidroaviões levavam a carga para os Estados Unidos. Os sonhos e as promessas também voltaram. O paraíso estava aqui, no Amazonas, era o que se dizia. O que existiu, e eu não esqueci nunca, foi o barco Paraíso. Atracou aí embaixo, na beira do barranco. Troxe dos seringais do Madeira mais de cem homens, quase todos cegos pela defumação do látex. Lá onde ficava a Aldeia, o prefeito mandou derrubar a floresta para construir barracos. E um novo bairro surgiu: Cegos do Paraíso." (HATOUM, 2009, pp.94,95.)

Este abandono estranho de um lugar, justifica-se desde o começo do livro, com a citação de Konstantino Kaváfis, “...sempre chegarás a esta cidade. Não esperes ir a outro lugar. Não há barco nem caminho para ti...”. A imagem do barco, a imagem do rio, a imagem do sonho mirabolante que corre, o tempo todo, estão poeticamente presente no romance. Um romance cuja leitura flui realmente como um rio, numa espécie de transe, miragem, mítica, que nos efetua um encantamento cinematográfico. Um encantamento que, em suas imagens, atinge o expressionismo alemão, no tocante à perda da fé no mundo burguês.

Hatoum não precisa buscar outro lugar, seu barco é o mundo, o que escorre ali não é apenas a seiva da seringueira, mas todo suor de uma ficção utópica e atópica, não apenas um auto-desafio da própria literatura, mas também um sonho épico que persiste...

"Vou embora para outra terra, encontrar uma cidade melhor. Para onde olho, qualquer lugar que o olhar alcança, só vejo miséria e ruínas"(HATOUM, 2009, p.95)

Senti um abafamento; o cheiro e o asco dos insetos me deram um suadouro. Lá fora, a imensidão do lago e da floresta. E silêncio. Aquele lugar tão bonito, o Eldorado, era habitado pela solidão" (HATOUM, 2009, p. 102)

Tal como o herdeiro do patriarcal Amando - a personagem Arminto Cordovil, espécie de "Don Juan" do Amazonas, não pode fugir do objetivismo que o rodeia, mesmo assimsonha, expressa emoção. Este, numa narração autodiegética, contradiz seu pai, o explorador da borracha, bem como o advogado grego Estiliano, dentre outras personagens como Florita. Ele é um anticapitalista solitário, buscador de poesia, de justiça, da destruição de oportunismo e, nas palavras do próprio autor em recente entrevista, da "desfaçatez da política”. O protagonista vai em busca de seu próprio ideal de amor, sua própria história, sua ilha, no final das contas.

“De onde ela veio?

De um lugar qualquer.

Mas não dessa ilha."(HATOUM, 2009, P.40) 
"Minha história com Dinaura começou naquela semana. Ela queria namorar comigo. Agora sou uma carcaça, mas fui um jovem vistoso. E ainda tinha posses. Isso conta, não é? Era o que eu pensava. Mas a riqueza não foi suficiente. Quer dizer, não serviu para muita coisa. A gente se encontrava a os sábados, não havia folga para outras tardes de amor. (HATOUM, 2009, p.40)

Talvez Hatoum possa embaçar, com seu estilo simples e brilho ao descrever a história passada na pequena Vila Bela, cidade inspirada em Parintins, uma série de não-lugares das espacialidades urbanas dos "bons" autores contemporâneos do romance brasileiro. Tais autores, muito estudados no mundo universitário, como por exemplo João Gilberto Noll ou Bernardo Carvalho; com freqüência, aproximados, em dissertações e teses pós-utópicas, com o campo do cinema, por seus estilos fragmentários, saturados pela dispersão, onde o vazio do mundo está bem marcado pela potência imagética. Efetivamente, "Órfãos do Eldorado" não se demonstra tão performático, hipereal ou cheio de personagens condenados ao exagero, quais os sujeitos pósmodernos representados por Noll ou Carvalho, mas não deixa de representar a violência ou ser menos cinematográfico por isso. Muito menos, de focar a dramaticidade e o vazio do mundo. Ao contrário, vale repetir que há um contato bem intenso com os filmes de Hersog, por exemplo. O que ocorre é que Hatoum, estilisticamente, busca ainda a confiança do leitor, a partir de toda uma fé mítica, e não propriamente a desconfiança, o que o faz mais clássico, mais "duque", mais machadiano inclusive. Essa confiança, a partir do poético das paisagens, do sonho, das imagens, é parecida com aquela bem legível na leveza de filmes como "Nosteratu, Phanton Der Nacht" (Nosferato, o vampiro da noite"), de 1979, ou o famoso "Jeder Für Sich Und Gott Gegen Alle" (O Enigma de Kaspar Hauser).

Mas, longe de querer afirmar alguma influência na composição de Hatoum, os filmes de Herzog que mais lembram o "Órfãos do Eldorado" vêm a ser: "Fitzcarraldo", de 1982, e "Aguirre, Der Zorn Gottes" ("Aguirre, a cólera dos deuses"), filmado dez anos antes. Aliás, se chamamos acima Hatoum de "duque" do romance contemporâneo brasileiro, vale lembrar, novamente, de Werner Herzog, cujo nome verdadeiro era Werner Stipetić. "Herzog" significa, em alemão, "duque", precisamente. De modo que a grandiloqüência e as frustrações de Arminto Cordovil poderiam muito bem serem representadas por um ator como Klaus Kinsk. O roteiro do primeiro, "Fitzcarraldo", é justamente a realização de um sonho impossível de um homem que se destaca dentre os nativos, na busca do Eldorado, que vem a ser a exploração da borracha na Amazônia. É aquele filme onde há uma cena surreal de um navio branco de mais de cem metros de comprimento atravessando uma montanha íngreme, em plena selva escura. 
"Os rumores no porto era desencontrados. Diziam que o comandante do Eldorado estava bêbado; que ele tinha desviado a rota para ver uma amante em São Francisco de Jararaca; que a chuva e o excesso de carga tinham provocado o acidente." (HATOUM, 2009, p.54).

Klaus Kinski atua também como o "Dom Lope de Aguirre", no segundo filme, que vem a ser outro, na verdade o primeiro, a tematizar a busca do Eldorado, a cidade de ouro, no séc XVI, por uma expedição de espanhóis exploradores.

São filmes utópicos, que tematizam a exploração de modo muito leve, os sonhos literários da natureza humana, com suas obsessões e frustrações, diante de uma paisagem expressiva. Exatamente como Hatoum o faz, neste feliz romance, cujas descrições, como as da Fazenda Boa Vida, são um pouco fruto de suas memórias de infância, e que, aliás, daria um magnífico roteiro para um filme a ser feito no Brasil. Quem assistiu ambos os filmes de Herzog, não vai deixar de lembrá-los ao ler “Órfãos do Eldorado”. Um livro simples e maduro, ao mesmo tempo, onde o leitor é colocado na condição desconfiada de se estar a ouvir uma narração lendária...

"Voltei para Vila Bela e fiquei escondido aqui, mas estava muito mais vivo. Ninguém quis ouvir esta história. Por isso as pessoas ainda pensam que moro sozinho, eu e minha voz de doido. Aí tu entraste para descansar na sombra do jatobá, pediste água e tiveste paciência para ouvir um velho. Foi um alívio expulsar esse fogo da alma. A gente não respira no que fala? Contar ou cantar não apaga nossa dor? Quantas palavras eu tentei dizer para Dinaura, quanta coisa ela não pôde ouvir de mim. Espero o macucauá cantar no fim da tarde. Estás me olhando como se eu fosse um mentiroso. O mesmo olhar dos outros. Pensas que passaste horas nesta tapera ouvindo lendas?" (HATOUM, 2009, p.103)

Fica, então, aberto o convite de uma viagem magnetizadora, mitológica, aos velhos sonhos dos ribeirinhos da Amazônia.

\section{REFERENCIAS}

HATOUM, Milton. Órfãos do Eldorado. São Paulo: Cia das Letras, 2009.

COLEÇÃO Werner Herzog. Direção: Werner Herzog. Produção: Werner Herzog. Alemanha: 4 filmes; Versátil Home Video, 2005. 4 DVDs (473 min.) son., color. 